https://jurnal.ugm.ac.id/rubikon

\title{
MAGISTERIUM AS THE ENEMY OF LIBERAL THOUGHTS IN PHILLIP PULLMAN'S NORTHERN LIGHTS
}

\author{
Nabil Bakri \\ e-mail: nbakri@ rocketmail.com
}

\begin{abstract}
Pullman's Northern Lights is considered by many as a representation of negative criticism toward religion, especially Christianity, for its depictions of the Magisterium. Many researches aim to unravel Pullman's criticism and prove whether or not the novel is about 'killing God', resulting in the general perception that Northern Lights is a condemnation of religion. By comparing the novel to the history of Medieval Church and the power of Magisterium to the Bible, this analysis means to prove whether or not the criticism is addressed to religion and to figure out who really 'kills God' that becomes the essential point of Pullman's criticism in the novel. Using Marxism and its relation to power abuse, this analysis attempts to relate Pullman's Magisterium to the real Magisterium and how the institution gains its power from God as mentioned in the holy Bible. Magisterium in Northern Lights does not represent God's will. It serves instead as a critic of who kills God and therefore, it is not a form of literature to condemn religion.
\end{abstract}

Keywords: magisterium; medieval church; scripture; fantasy; power abuse

Article information

Received: 9 August, 2019

Revised: 23 August, 2019

Accepted: 6 September, 2019

DOI $\quad$ : https://doi.org/10.22146/rubikon.v6i2.61493

Available at https://jurnal.ugm.ac.id/rubikon/article/view/61493

This work is licensed under a Creative Commons Attribution-ShareAlike 4.0 International License

\section{INTRODUCTION}

In 2007, New Line Cinema (which previously gained its highest momentum as it released The Lord of the Rings Trilogy) released The Golden Compass, a then new fantasy film based on the work of English novelist Philip Pullman. The film was released during the public's continuing fascination toward fantasy as it was released at the exact same time continuum or paradigm as Disney's The Chronicles of Narnia (which was about to release its second entry Prince Caspian), Warner's Harry Potter, and Fox's (now Disney after Disney CEO Bob Iger officially purchased $20^{\text {th }}$ Century Fox) Eragon. It was certainly before the age of Superhero films (as Iron Man was released merely a year after The Golden Compass and started the long journey 
of the Marvel Cinematic Universe) and therefore, the film was expected to be both critically and financially successful. It was rather safe to assume that the film would be a success considering the achievements of its already popular source material and the growing success of fantasy series (namely The Lord of The Rings, Harry Potter, and the then newest entry The Chronicles of Narnia: The Lion, The Witch, and The Wardrobe) and yet, the film tanked in the box office chart and completely shut any opportunity for its sequel to be filmed.

One of the most recognizable film critics Roger Ebert gave The Golden Compassa perfect $4 / 4$ score, noting that the film is actually "a darker, deeper fantasy epic than the "Rings" trilogy, "The Chronicles of Narnia" or the "Potter" films" (Ebert, 2007). The Golden Compass was considered a Special Effect masterpiece, indeed, as the DVD released after the Academy Awards ceremony boldly included the Oscars' Best Visual Effect of 2008 logo to show the gravitas of the fantastical innovations in the recreation of the novel's fantastical storyline. However, according to Box Office Mojo(a popular box office count aggregator, an international online gateway to films' financial reports), the film could only make $\$ 372$ million from its $\$ 180$ million production budget. Regardless of how Ebert praises the film, the numbers cannot be manipulated, meaning that the film was a financial nightmare that can be interpreted as a proof of extremely low numbers of viewers, and The Guardian even released an article under the title "The Golden Compass recap: how a literary triumph was turned to dust" in 2013 to remember how bad the film really was and how an opportunity was skillfully wasted to dust. It is logical, then, for one to ask the obvious question of why the film based on a bestseller released during the peak of fantasy film trend could ended up as a forgotten piece of Technicolor reels. The Los Angeles Daily News, however, found a rather surprising reason regarding the failure of the film during an interview with Reverend Greg Garman that Christians were being encouraged not to see the film (Daily News, 2007). This surprising discovery led to the investigation of the source material which is the actual book written by Philip Pullman, Northern Lights.

It is widely known that Philip Pullman is an atheist and his famous work His Dark Materials trilogy is criticized for being a condemnation towards religion (especially Roman Catholicism and Christianity). The writer himself even stated that his book is actually 'about killing God' and therefore, he was actually expecting for negative responses from readers all over the world, though finally Rowling's Harry Potter surpassed its controversies and hid Northern Lights tightly 'below the radar' (Bruner from Garrahy, 2009, p. 106). Most readers, however, might not be aware that the depictions of an authoritative institution called the Magisterium is believed, by many critics, religious leaders, and Pullman himself, to be Pullman's criticism towards religion. Unlike many non-Catholic readers who might guess that the Magisterium in Northern Lights is simply a make believe institution equal to the church or Papacy, readers belong to Christianity or Roman Catholicism are supposed to notice the fact that there really is an institution named the Magisterium under the Papacy in the real world-The Magisterium in Northern Lights is parallel to The Magisterium in the reality. Yet, many young adults do not notice the actual 
meaning of his Magisterium disguised beneath Pullman's fantastic words in Northern Lights.

Pullman's extraordinary ability to deliver his visions of fantasy through words makes Northern Lights a highly favorable novel among young adults. Northern Lights wins The Carnegie Medal and the Guardian Award, for it mesmerizes not only children and young adults, but also adults who fall in love with its fantastic-adventurous theme. The fascination towards the work, however, usually makes it impossible to unravel hidden messages behind its chapters because the readers usually have no time to scrutinize the work during the reading process. They really become attached to the adventure, mystery, and action depicted by the novel and the eagerness to know 'what is next' so they simply miss, or sometimes ignore, Pullman's intentional message to 'kill God'. Nevertheless, readers who read it more carefully or simply have an understanding of the Papacy, will be able to recognize the writer's criticism towards religion.

In Fantasy in Northern Lights: Between Amusement and Ideology, Rihane concludes that there is no children's or young adult's literature that is free of ideology $(2013$, p. 7). Pullman manages to delight young readers as well as adults so they mostly miss the hidden ideology concealed in the work. However, it does not mean that there is no hidden ideology at all in the work, for a hidden message is something that embodies each and every literary work including Northern Lights. Although the popularity of the elements of fantasy in Northern Lights eventually surpass the popularity of hidden ideology in the book, Pullman explained that there are hidden meanings of his work and those meanings are intended to be discovered by readers. In fact, Pullman was so ready for massive backlash but ended up being surprised that his controversial masterpiece was actually less debated than theHarry Potter series despite containing more sensitive issues - the way Northern Lights view the Fall or sin of man being one of those issues.

In Northern Lights, Pullman does not resemble the Fall of human simply as a 'sin' like those depicted by C.S. Lewis in his popular series, The Chronicles of Narnia. Lewis, who was extremely open about his conservative-religious views in both his life and his works (in both academic and nonacademic) (Colbert, 2006), wrote the Fall as somewhat destructive and therefore the depictions of the ideology of good and evil arevividly described. According to Northern Lights, however, the Fall cannot be seen as something negative, for it is necessary in the shift from childhood into adulthood- that to experience $\sin$ is a natural part of the process of growing up (Cuthew from Rihane, 2013, p. 5). Thus, instead of interpreting the act of killing as a sin, for example,Northern Lightsquestions whether the act of killing is a sin if it is based on a right purpose. The main character Lyra questions the notion of whether Dust (a mysterious particle) is purely wicked as adults say, or is actually good, which means that the adults are wrong or being manipulative to their children.

The hidden ideologies areat hand and soon after the hype of criticizing Harry Potter grew dim, people started to criticize and condemn Northern Lights. In 2002, Peter Hitchens from The Mailon Sunday titled Pullman as the most dangerous author in Britain (Garrahy, 2009, p. 106). Jessica 
Garrahy in her journal His Controversial Materials: Pullman and Religious Narrative Identity published on 19 December 2009 in Literature and Aesthetics explains how most readers are likely to view Northern Lights, its criticism towards religion, and its ability to change people's religious belief, in certain ways. However, to change someone's belief is not an easy task and though Northern Lights might have the ability to do so, Garrahy believes that it is not supposed to change someone's belief, but to open further discussions about religion for a better understanding on human history and humanity itself.

Pullman claimed that his book is about 'killing God' and many people address their negative responses to it. People belong to Christianity find the novel as an insult to their religion and many critics agree with their perspectives. However, does Northern Lights really kill God? In order to explain evidences about Pullman's criticism towards religion in his novel, apparently, is not a difficult task and to do so will not make this analysis the first, but to answer whether or not the criticism really is addressed to religion is rather difficult, because there are lots of human's involvements in the forging process of Christianity that can make people wonder about the specific individuals that abuse religious power bestowed upon them. The power bestowed upon religious leaders, similar to any kind and/or access to power, according to Karl Marx, is prone to power abuse causing conflicts between social classes (Barry, 2009, p. 167). This analysis means to disclose the origin of power bestowed upon religious leaders involved specifically in the Magisterium and the actual target of criticism in Northern Lights. In order to do so, this analysis sought confirmation regarding the proper use of a valid theory from Karl Marx's ideas, the Marxist theory concerning power within societies.

People have been led to believe that their ideas, their cultural life, their legal systems, and their religions were the creations of human and divine reason, which should be regarded as the unquestioned guides to human life. Marx reverses this formulation and argues that all mental (ideological) systems are the products of real social and economic existence. The material interests of the dominant social class determine how people see human existence, individual and collective. Legal systems, for example, are not the pure manifestations of human or divine reason, but ultimately reflect the interests of the dominant class in particular historical period (Selden and Widdowson, 1993, pp. 70-71).

Based on the excerpt added previously, it is clear that the Marxist theory does indeed tackle with the matters of power within human societies. The theory is surprisingly in line with cultural studies which observes the correlations between power and the creation of popular cultures. According to cultural studies, power pervades every level of social relationships and acts as a concept that binds societies together since power enables social relationship and social order (Barker, 1999, p. 10). Marx's argument that human ideas, lifestyles, legal systems, and religions are "products of real social and economic existence" provides the idea that those concepts (including religions) are created out of social interactions and powers, bearing certain mortal (instead of divine) interests. Newer idea concerning the initial reason of the establishment of religions is addressed by Yuval Noah Harari in Sapiens: A Brief 
History of Humankind (2015) which concludes that, based on historical perspectives, religion emerges through human's need to thrive through teamwork (Harari, 2015, pp. 209-236). Ideas on power do not necessarily mean to demolish power (and religion) because those very same ideas also acknowledge the importance of power (and religion) in the existence of humankind. However, those ideas allow the public to question the bearers of power, their motives, and whether or not they abuse their powers. This kind of correlation between power and the abuse of power is ultimately scrutinized in this qualitative analysis.

\section{DISCUSSION}

Northern Lights, popularly known as The Golden Compass, tells the story of a mischievous girl named LyraBelacqua who views the world as the place of adventures and her acts resemble her belief that all rules are made to be broken. Her uncle, a highly respected scientist Lord Asriel, put her in Oxford's most respected College called Jordan in which she learns about secrets considered as restricted by the supreme institution, the Magisterium. The institution controls not only people's religious aspects but also every single aspect of human's life, including politics, science and what should and should not be taught in schools and colleges. The Magisterium considers any science related to a mysterious particle known as Dust as a conviction of defiance towards the institution and therefore the subject who practice the research of Dust should be punished. The punishment is not always given by the institution directly, but it is also possible for people in general to punish the action of disobedient towards their ultimateruler. Jordan Master's plan to kill
Lord Asriel to stop him from a further study on Dust in the second chapter of the novel shows his fear of the Magisterium and the terrible cost Lord Asriel, Jordan, and Lyra should pay if Lord Asriel continues his scientific research on Dust, for it is widely known that the study of Dust is restricted as the Master talks to the librarian, "Hardly anyone would be happy for that idea (to kill Lord Asriel), Charles. The question was whether doing that would be worse than the consequences of not doing it," (Pullman, 1995, p. 20). It is clear, then, that to defy the Magisterium means to defy literally everyone, even one's dearest friend, for the Magisterium's rules are made to be absolute and its punishments are undoubtedly fearful.

Since the death of Pope John Calvin, the Papacy is abolished and the Magisterium takes its place as the supreme power to control people's life. The Magisterium has the total power claimed to be given by God to govern practically everything and therefore, there are only two possibilities of rules: whether something is good or bad (or whether something is right or wrong). There is no room for questions and once an action is sentenced as 'bad', people must accept the belief that the action is 'bad'. Lyra, however, questions whether or not Dust is 'bad' since the Magisterium (and everyone) say that Dust is bad and evil, and therefore motivate Lyra's curiosity to prove whether Dust is truly evil or there might be a chance that it is actually good. The particular plot criticizes the fact that people cannot question God while Pullman's character cannot stop her question because the decision made by the Magisterium for science is somewhat illogical. The way the Magisterium is explained in the novel and Lyra's thoughts and actions to defy the institution make many 
people believe that Pullman has an intention to criticize religion, for any action to defy the institution means to defy God Himself.

Rihane believes that Northern Lights carries different ideologies of sexuality, morality, and religion. Since he analyzes the novel as a children's literature, he means to prove Peter Hunts' claim that no children's text is free of ideology (2013, p. 7) though a children's literature might be able to provide the reading enjoyment so the reader cannot perceive the ideology hidden by the author. Similar to public's opinion, Rihane mentions 'religion' as one of three major ideologies Pullman gave to his novel with the religion ideology being the strongest point. On her journal, Garrahy explains about the religious controversy and many scholar's and Christian's condemnations toward Northern Lights. Though she does not criticize the novel as being a criticism towards religion, she examines how people should react towards the controversy. Both Rihane and Garrahy do not defy nor deny the public criticism upon the novel and therefore strengthening the belief that Northern Lights is a refusal of God and religion.

It is not surprising and rather logical that people interpret the novel as a religion critic, and an important one since it is published as a children's book. However, the fact that it is written for children while it has what people believe as the 'wrong' ideologymakes many people suggest that the novel should be banned. Rihane, in his conclusion, says that Pullman's novel can be considered as being intrusive on some levels and may be seen by conservatives as downright sinister (2013, p. 7). The petition to ban the book and people's seemingly endless hatred towards the novel suggestan in depth analysis onNorthern
Lights to unravel its true criticism and to whom it is addressed. A skeptical attitude to people's criticism is necessary since the writer does expect such responses from the readers (Garrahy, 2009, p. 106) and therefore being suspicious towards people's suspicion of the novel's position as a religion critic is reasonable.

\section{Magisterium and the Medieval Church}

The medieval period shows the growth of church that leads to the wealth of ministers, monks, and nurses. Karen Armstrong in The Battle for God: A History of Fundamentalism mentioned about the growthin medieval European and that 'Life was slowly becoming secularized in Europe...' and how 'the increased productivity and healthier livestock affected everybody's life' (2000, pp. 62-66). The proof that the wealth brought negative impact came from Martin Luther (1483-1546) who was one of the first Europeans to promote the separation of church and state. Martin Luther condemned the coercive methods of the Roman Catholic Church to use the state to impose its own rules and orthodoxy (Armstrong, 2000, p. 67).

The petition to separate politics and religion designates the indication that the Church misused its power for its own benefits and no one should question the Church's activity to gain wealth through its privilege given by God. Pullman's Magisterium, once a respected religious institution, misused its power and transforms itself into a divine yet fearful institution dictating people's life. The Magisterium claims that their dictation is for the benefits of the society, but apparently there is no other option but to obey the Magisterium and 
therefore, it is not an effort to bring benefits to the society, but a force to make the society obey the Magisterium. The teaching of the Magisterium, which concerns of both religious and secular aspects, is claimed to be the teaching of God and therefore, not even a scholar is permitted to examine Dust scientifically, for it is banned by the institution. The Magisterium in Northern Lights is an extreme example of power abusethat is not entirely impossible to happen in the real world since such abuse in which people in religious power do anything to keep his power and privilege at hand already happened in the medieval church, though it was not as extreme as Pullman's Magisterium. A question of how it is possible for a religion institution to misuse its power emerges. In order to answer the question, however, it is necessary to analyze how the institution gained its privilege, started from the beginning of Jesus' ministry (Pollock, 2002, p. 13) stated in Luke 4:16-19:

And he came to Nazareth, where he had been brought up; and, as his custom was, he went into the synagogue on the Sabbath day, and stood up for to read.

And there was delivered unto him the book of the prophet Isaiah. And when he had opened the book, he found the place where it was written,

'The spirit of the Lord is upon me, because he hath anointed me to preach the gospel to the poor; he hath sent me to heal the broken-hearted, to preach deliverance to the captives and recovering of sight to the blind, to set at liberty them that are bruised.'

To preach the acceptable year of the Lord. (Luke 4:16-19)

The Lord asked Jesus to preach the gospel, but Jesus did not spread his teachings all by Himself. He gathered the apostles, the early Christians embarked on journeys to spread the gospel, to form a teaching authority to pass and spread Jesus' teachings. The role of the apostles then succeeded by bishops and the assembly is called the Magisterium which means 'teaching office'. Although the Magisterium is under the authority of the scripture, it does have a power, that is, 'The Magisterium speaks with the authority of Christ, guided and empowered by the Spirit of Truth' (D'Ambrosio, 2016) and therefore, it is infallible. The privilege, however, is given in order to support the process of teaching the gospel and not to support bishops' personal interests. Bishops, though they hold the teaching role, share the teaching duty with the Pope who is considered as the successor of Peter, one of the discipleswhom the apostles gathered around to. Thus, as Jesus gathered the apostles around Peter, the relation between bishops and the Pope in the teaching process is inseparable. Pollock explains the influence of Peter which makes the evolvement of his successor, the Pope, in the Church essential:

Given the information from the gospels, it's not surprising that Peter should emerge immediately after the death of Jesus as the leader of the earliest church. Peter dominated the community for nearly fifteen years following the Resurrection. It was he who raised his voice and preached at Pentecost, the day when the church came into being. It was he who served as an advocate for the apostles before the Jewish religious court in Jerusalem. It was he who led the others in extending the church...(2002, p. 18).

Indeed, Jesus Christ is considered as the invisible head of the Church, but it is believed that by his authority the Pope becomes the visible head of the Church (Pollock, 2002, p. 27). He is the ultimate 
teacher of the gospel inspired by the Holy Spirit and therefore he is considered as a person unable to make any error in the matter of teaching the gospel. The Magisterium, which then also becomes infallible, teaches discipline, doctrine and dogma. Discipline is the rules made by the Church related to the current moral aspects and manners, which means it depends very much on the current paradigm and the teachings will be changed if the paradigm is shifted. Doctrine and dogma, on the other hand, are the truth spoken by God and therefore, they do not change through time (D'Ambrossio, 2016). In order to ensure the continuity of passing the gospel through generations, it is necessary to give the Pope, bishops, and the Magisterium the authority to make certain rules so that the teaching process meets no obstacles. With information provided by the religion, D'Ambrossio explains the privilege of authority and infallibility owned by the Magisterium:

So while there are different sorts of Magisterial teaching with differing degrees of authority, the willingness to submit loyally to the Magisterium must be the rule, even if that teaching is not per se infallible. For the Church is no mere human institution. Birthed by the Spirit, it was endowed with the Spirit with certain gifts. One of the greatest of those gifts is the charisma of truth given to the apostles successors that guarantees that the Church will remain a pillar and bulwark of the truth (I Timothy. 3:15) till the end of time (D'Ambrossio, 2016).

Phillip Pullman does not describe the Magisterium the way it is in the real life. Though it is clear that the Magisterium needs the Pope's authority, Pullman's Magisterium abolishes the Papacy and becomes a divine institution made up of several different authorities. These authorities make the
Magisterium no less than a government institution that governs both religious and secular aspects. There are The Consistorial Court of Discipline, The General Oblation Board, The Society of the Work of the Holy Spirit, and other institutional parts of the Magisterium involved in political fights. Pullman describes it not as an institution as we know it, but a religion institution of which religion is not the ultimate concern and goal, but a tool to control politics, cultures, and social lives. The description of the Master's conversation with the Librarian shows how the Magisterium turns into a fearful institution.

The Librarian was silent in his turn. Ever since Pope John Calvin had moved the seat of Papacy to Geneva and set up the Consistorial Court of Discipline, the Church's power over every aspect of life had been absolute. The Papacy itself had been abolished after Calvin's death, and a tangle of courts, colleges, and councils, collectively known as the Magisterium, had grown up in its place. These agencies were not always united; sometimes a bitter rivalry grew up between them. For a large part of the previous century, the most powerful had been the College of Bishops, but in recent years the Consistorial Court of Discipline had taken its place as the most active and the most feared of all the Church's bodies (Pullman, 1995, p. 21).

The religion makes the Magisterium infallible, but abolishing the Papacy would be a violation to the religion which clearly made the Papacy, bishops, and the Magisterium inseparable. Jesus made the Pope the head of the church based on the influence of Peter and the apostles who then became responsible to the Magisterium. Pullman's Magisterium terminates the Papacy and therefore terminates the right of 
its divine authority, for it is not possible to have one without the other (D'Ambrossio, 2016). The Magisterium in Northern Lights, then, has no rights to claim the God given authority to pass its teachings. Christianity does not give its authority to the Magisterium to eliminate the Papacy and to control every aspect of life. Thus, the Magisterium described in the novel does not represent the teaching of Jesus and Christianity.

\section{Magisterium, the Holy Bible and Power Abuse}

Pullman's Magisterium exercise its authority to the society and therefore, it signifies the term 'power abuse' mentioned by Abel Haon in his paper "Identifying Leadership Power Abuse and its Prevention in the Local Church Context". The way the Magisterium allows any possible precaution to prevent a further 'independent study' of Dust shows how the institution forces its teachings to be 'blindly' accepted by the society. The word 'blindly' has a relation to the phrase 'independent study' and signifies an even further power abuse done by the Magisterium, for the institution does not purely eliminate scientific research, but controls and/or supervises any scientific research if it to be conducted. However, the relation suggests a contradiction. The Magisterium allows only its division to analyze Dust and therefore, it is impossible to expect the result of the research to be independent or objective (unbiased). Thus, people can only accept the information of Dust provided by the institution 'blindly' with no room to question its validity or even its methodology. Abel Haon recites David Johnson and Jeff VanVonderen'swriting about 'spiritual abuse', a term in which in many aspects included in the term 'power abuse':

Likewise, those in spiritual positions of authority can violate our trust. It's possible to become so determined to defend a spiritual place of authority, a doctrine, or a way of doing things, that you wound and abuse anyone who questions, disagrees, or does not "behave" spiritually the way you want them to. When your words and actions tear down another, or attack or weaken a person's standing as a Christian - to gratify you, your position, or your beliefs, while, at the same time, weakening or harming another - that is spiritual abuse (Johnson and Van Vonderen from Haon, 2013, p. 106).

The Magisterium earns its authority from God. This fact makes people think that Northern Lights insults Christianity simply because the religion gives such power and infallibility to the Pope and bishops. The novel becomes more than a mere fantasy literature but a question to religion, doubting the decision of bestowing the divine authority to the 'mere' people while it is indeed no room for questions in religion or it will not be a religion at all, for the decisions of God means the end of the discussion - it is, by all means, absolute (D'Ambrossio, 2016). However, the Holy Bible does not allow any person or institution with the privilege of power from God to exercise the power for any reason but to teach the gospel through kindness. The books of Matthew and Mark in the Bible contain almost similar verses talking about power abuse among many other books and verses about the same subject:

But Jesus called them unto him, and said, Ye know that the princes of the Gentiles exercise dominion over them, and they that are great exercise authority upon them. 
But it shall not be so among you: but whosoever will be great among you, let him be your minister:

And whosoever will be chief among you, let him be your servant:

Even as the Son of man came not to be ministered unto, but to minister, and to give his life a ransom for many. (Matthew 20: 25-28)

Indeed the religion asks the successor of Peter to teach the gospel and he is attributed with infallibility through the guidance of the Holy Spirit, but he must not 'exercise authority upon them' (the people) and he is bowed to 'give his life a ransom for many'. The rules are obvious among the privileges and it is said that the Holy Bible and Jesus Christ are the ultimate authorities to spread the words of God and therefore, the Pope and the Magisterium are bowed to the ultimate authorities. Thus, there is nothing wrong with the religion as long as it remains pure. In Northern Lights, however, the authorities secularize the religion and therefore, it is 'they' (people bestowed with divine authorities) who exercise their powers through spiritual abuse which is a form of power abuse. Thus, Northern Lights examines the phenomenon so close to human beings which Karl Marx believes comes along the way with power (Barker 2000, p. 10) that leads to conflicts between (social) classes (Barry, 2009, p. 167).

Pullman's Magisterium consists of several institutions in which all of the institutions fight for the highest position though they belong to one major institution. The competitions between institutions, however, do not disrupt Magisterium's works to govern the society. Despite of the Magisterium's fearful decision to eliminate freedom, the institution assure that their rules are for the society's benefits. The General Oblation Board, which has the responsibility to eliminate Dust, assures the society that Dust is the representation of sin and therefore must be destroyed. The reason to interpret Dust as the representation of sin comes from the fact that Dust only attracted to adults and adolescence and not to children before puberty. Thus, Dust appears and attracted to someone only after he commits his first sin intentionally. To analyze the phenomenon using kidnapped children, members of the General Oblation Board justify their action by assuring themselves and all who got themselves involved in the process that 'it is for their (the kidnapped children's and children in general) good as well as ours' and blatantly reject to call the children they kidnap as the sacrifice even though the children are treated as sacrificial objects:

Sacrifice is rather a dramatic way of putting it. What's done is for their good as well as ours. And of course they all come to Mrs. Coulter willingly. That's why she's so valuable. They must want to take part, and what child could resist her? And if she's going to use you as well to bring them in, so much the better. I'm very pleased." He smiled at her in the way Mrs. Coulter had as if they were both in on a secret. She smiled politely back and he turned away to talk to someone else (Pullman, 1995, p. 61).

The Magisterium uses the authority bestowed by Christianity to oppress the society which has to obey the institution because the 'oppression' is 'for their good as well as ours'. The institution is responsible for the abduction of children who will be the objects of their scientific experiments. However, they do not consider the abduction as a crime, but the children's spiritual determination, for they become the object 
'willingly'. It is clear, then, that the institution manipulates religion since the decision to eliminate the Papacy and becomes the supreme institution to govern every aspect of life in order to ensure their power and to fulfill its own interests. However, Christianity does not allow both power and spiritual abuse and therefore, the institution kills the gospel to create a new teaching based on the need of the institution.

\section{CONCLUSION}

The moment a reader finds out that Pullman is an atheist and an influential critic to give The Chronicles of Narnia, a highly respected religious series, a negative response, it is possible and reasonable that the reader will not view Pullman's descriptions of the Magisterium and Dust as mere fantastic plot but a piercing and rather straight-forward criticism towards Christianity. Though there are many people express their negative responses toward the novel for its content, there are many people who criticize Northern Lights for its target reader. It is considered fine for a novel to carry subtle and controversial ideologies, but not as a children's (and young adult's) book. Apart from the readers' mixed responses, however, the Bible provides the evidence that the power abuse done by Pullman's Magisterium is not allowed by Christianity (and other religions) and therefore, Northern Lights means to criticize people who own religious authority and act as a reminder that 'power' can be used for both good and bad deeds. Northern Lights perfectly captures Thomas Jefferson's criticism recited by Richard Dawkins in his controversial book The God Delusion, "The priests of different religious sects...dread the advance of science as witches do the approach of daylight, and scowl on the fatal harbinger announcing the subdivision of the duperies on which they live" (Dawkins, p. 137). As a result, it is obvious that the point of the criticism is 'the priests' and not the 'different religious sects', meaning that Northern Lights does not criticize Christianity as a religion, but the Christian authorities who deliberately use their power to manipulate others for their own benefits - those religious leaders, Northern Lights put it simply, are the true form of hypocrisy in human society.

\section{REFERENCES}

Adamson, Andrew (Director). (2005). The Chronicles of Narnia: The Lion, the Witch and the Wardrobe. The Walt Disney Company/Buena Vista Distribution/P.T. Vision Interprima Pictures: DVD (Digital Versatile Disc) Region 03/NTSC SLS NO: 154/DVD/R/PA/9.2009/2008.

Armstrong, Karen. (2000). The Battle for God: A History of Fundamentalism. New York: The Ballantine Publishing Group.

Barker, Chris. (2000). Cultural Studies: Theory and Practice. London: SAGE Publications Ltd.

Barry, Peter. (2009). Beginning Theory: An Introduction to Literary and Cultural Theory (Third Edition). Manchester: Manchester University Press.

Box Office Mojo (Editors). (2019). The Golden Compass. Retrieved July 11, 2019.

Colbert, David. (2006). The Magical Worlds of Narnia. Jakarta: Gramedia Pustaka Utama. 
Colbert, David. (2006). The Magical Worlds of The Lord of the Rings. Jakarta: Gramedia Pustaka Utama.

D'ambrossio, Marcellino. (2016). What is the Magisterium and Why Do We Need It?. Retrieved April 29, 2016, from www.crossroadsinitiative.com

Daily News (Editors). (2007). Controversy over Golden Compass. Retrieved July 11, 2016, from www.dailynews.com

Dawkins, Richard. (2006). The God Delusion. Great Britain: Bantam Press.

Ebert, Roger. (2007). The Golden Compass. Retrieved July 11, 2019, from www.rogerebert.com

Garrahy, Jessica. (2009). His Controversial Materials: Philip Pullman and Religious Narrative Identity. Literature and Aesthetics, 19(2), 105-122.

Graham, Gordon. (2005). Philosophy of the Arts. New York: Routledge.

Haon, Abel. (2013). Identifying Leadership Power Abuse and its Prevention in the Local Church Context, Melanesian Journal of Theology. 29(1), 104-122.

Harari, Yuval Noah. (2015). Sapiens: A Brief History of Humankind. New York: Harper Perennial.

Heritage, Stuart. (2013). The Golden Compass Recap: How a Literary Triumph was Turned to Dust. Retrieved July 11, 2019, from www.theguardian.com

Jackson, Peter (Director). (2001). The Lord of the Rings: The Fellowship of the Ring (Extended Edition). New Line Cinema: BD (Blu-ray Disc) Region Code A (includes USA and Indonesia) (International Edition, SLS number not included, ISBN/Code 1-10563-94043-

0)

Lukens, Rebecca J. (1999). A Critical Handbook of Children's Literature. New York: Longman.

Pollock, Robert. (2002). The Everything®: World's Religions Book. Maryland: Adams Media.

Pullman, Philip. (1995). The Golden Compass. New York: A Knopf Paperback.

Rihane, Mohammad Walid. (2013). Fantasy in Northern Lights: Between Amusement and Ideology. Retrieved February 25, 2016, from academia.edu

Selden, Raman and Peter Widdowson. (1993). A Reader's Guide to Contemporary Literary Theory. New York: Harvester Wheatsheaf.

Weitz, Chris (Director). (2007). The Golden Compass. New Line Cinema/P.T. Duta Cinema Multimedia: VCD (Video Compact Disc) Region 03/PAL SLS NO: 621/VCD/D/PA/02.2010/2008. 